\title{
Combined and Joint Operations at Sea: Some Reflections from History
}

\author{
Sarandis Papadopoulos ${ }^{1}$
}

This essay is indebted to the edited book You Cannot Surge Trust, in which the author played a part, extending its emphases here in three ways: foremost, navies must continually remain true to national political and strategic goals. ${ }^{2}$ Second, the tactical problem of uniting constantly manoeuvring sailing ships and, subsequently, operationally managing steam-powered vessels spread over wide areas are both harder than usually thought. In relation to that last point, it bears recalling that the 1944 Battle of Leyte Gulf was fought over an area larger than the countries of Afghanistan or Ukraine, or the American state of Texas. The immensity of the oceans therefore demands different types of military command and control than for land or air operations. Finally, and most intangibly, effective combined operations by maritime forces demands a human level of cooperation which cannot spontaneously arise or be improvised. Instead, participating navies must rely upon creating trust between those commanding and serving on ships in multinational operations to cement success.

Multinational, or combined, naval activities are older than commonly assumed. Whether dealing with the classical Greek city states' unified action against the Persian Empire at Salamis in 480 BCE, or both the Holy Alliance and their Ottoman opponents at Lepanto in 1571, combined operations are not new. That said, the coalition, alliance and empire taking part in these battles did not face the technical, tactical or command problems which have challenged more recent partnerships at sea. For example, at Lepanto both sides fought in similar patterns, integrating ships of different nationalities, even in multilingual squadrons. ${ }^{3}$ While strategically no-

1 The comments and opinions of the author here are personal and do not represent those of the Department of the Navy, Department of Defense or the United States Government.

2 Gary Weir and Sandra Doyle (eds.), You Cannot Surge Trust: Combined Naval Operations of the Royal Australian Navy, Canadian Navy, Royal Navy, and the United States Navy 1991-2003 (Washington: Naval History and Heritage Command, 2013).

3 John F. Guilmartin, Gunpowder and Galleys: Changing Technology and Mediterranean Warfare at Sea in the Sixteenth Century (London: Cambridge, 1974), 232-248. 
table, such combined battles were short-term and generally stood as exceptional cases.

In the modern era, multinational naval action, and problems, became more recognisable. Starting with the $17^{\text {th }}$ century Anglo-Dutch Wars, fleets of ships discerned by "rate", i.e. size, and globally distributed, created room for unified efforts. Still, manoeuvring ships under sail meant balancing what we today term command and control. When an English and French fleet fought the outnumbered Dutch in May and June 1673 off Schoeneveldt and Texel, poor communications played a role in allied tactical defeats. ${ }^{4}$ Failure at the second battle allowed the Dutch Rear Admiral Michiel de Ruyter to break off the action, preserving his force, saving the Republic from invasion and ultimately forcing England's Charles II to leave the war. Given the concentration of Dutch naval power, the allies had needed to take unified tactical action, but their ships fought together with difficultly and ultimately failed.

The next 150 years saw overseas colonies, and shifting naval alliances, absorb European attention. English naval power of the era generally meant continental nations united against it, forcing it to face naval alliances four times. Typically, these were loose strategic relationships, with navies waging war in parallel. Fifty-three major naval battles took place between 1688 and 1815 , seven with more than one navy on a side. More strategically, during the Seven Years War one-third of English merchant ships were captured by French and Spanish privateers. ${ }^{5}$ Only during the American Revolution did France, Spain and the Netherlands unite to create maritime success against Britain. ${ }^{6}$

Speaking jointly, this era's naval power delivered mobility never seen before. During the Seven Years War, British fleets supported expeditionary units against coastal France, creating what Julian Corbett called "the deter-

4 N.A.M. Rodger, The Command of the Ocean: A Naval History of Britain, 1649-1815 (New York: W.W. Norton, 2005), 84-85, Michael A. Palmer, Command at Sea: Naval Command and Control since the Sixteenth Century (Cambridge: Harvard, 2005), 60 and Brian Tunstall, Naval Warfare in the Age of Sail: The Evolution of Fighting Tactics 1650-1815 (Edison: Wellfleet, 2001), 35-37. See also Alfred T. Mahan, The Influence of Sea Power Upon History, 1660-1783 (Boston: Little Brown, 1890), $152-158$.

5 Sam Willis, Fighting at Sea in the Eighteenth Century: The Art of Sailing Warfare (Woodbridge: Boydell, 2008), 201-216 and Mahan, 318.

6 Larrie D. Ferreiro, Brothers at Arms: American Independence and the Men of France \& Spain Who Saved It (New York: A.A. Knopf, 2016), 248-254 for Spanish Gulf of Mexico operations, and 257-263 for the Anglo-French Battle of the Chesapeake. Compare with Mahan, 378-390. 
rent effect of troops upon the sea", maintained English troops in Hanover, as well as landing forces in Nova Scotia, Cuba, Guadeloupe, the Philippines and, most brilliantly, Quebec. ${ }^{7}$ This did not mean joint action at sea won every time, for several of these efforts took two attempts to succeed. Similarly, naval allies did not always win wars: despite strengthening each other off Toulon (1744), when a mixed Spanish and French fleet defeated the English, the battle was not decisive for the war's result. In 1805, a similar allied fleet was crushed at Trafalgar, effectively limiting Napoleon's maritime ambitions. Naval specifics were foremost, just as poor command and control had hindered the English at Toulon. In contrast, the outnumbered Vice Admiral Horatio Nelson faced a poorly supported Spanish navy, and post-revolution French crews, decapitated of good leadership, allowed superior Royal Navy ship-handling and tactical clarity to ensure the English were victorious. ${ }^{8}$

The ensuing "Pax Britannica" opened a maritime world analogous to the $20^{\text {th }}$ century's post-Cold War era, marked by rapidly rising trade. Naval missions became more elective, in support of a second colonial wave throughout the 1800s. The rules-based order behind this globalisation was heavily British in design and benefit, but not exclusively, with France another key influence. ${ }^{9}$ Simultaneously, after 1815 naval goals became nuanced, political and sometimes controversial, anticipating the need to create what we now term "rules of engagement". At Navarino in 1827, a British, French and Russian fleet sent to embargo weapons' shipments instead defeated a weaker Ottoman Turk and Egyptian force during the Greek War of Independence. London, however, then repudiated its own victorious Vice Admiral Sir Edward Codrington for easing Russian entry into the Balkans, despite domestic popularity for ending Ottoman control in southern Greece. ${ }^{10}$

After 1815 local multinational efforts arose to protect seagoing commerce using small forces. For example, British and American crews togeth-

7 Julian S. Corbett, England in the Seven Years War: A Study in British Combined Strategy (London: Folio Society, 2001), 437, and especially 321 for British operational ship-to-shore manoeuvre during the Quebec campaign.

8 Palmer, 202-207.

9 Rebecca Berens Matzke, Deterrence Through Strength: British Naval Power and Foreign Policy under Pax Britannica (Lincoln: Nebraska, 2011), 58-63.

10 Palmer, 208, Paul M. Kennedy, The Rise and Fall of British Naval Mastery (London: Ashfield, 1983), 167 and Lance E. Davis and Stanley Engerman, Naval Blockades in Peace and War: An Economic History Since 1750 (Cambridge: Cambridge, 2006), 389. 
er fought Caribbean piracy during the 1820 s, predicting similar missions almost 200 years later. ${ }^{11}$ Legal stability at sea grew as the new maritime order saw much of the world depart from mercantilism, heading to freer trade and conflict management backed by intimidation, and employing what would now be termed the globe's "oceanic commons". ${ }^{12}$

Maritime vastness meant all illicit trade could not be stopped, with West African anti-slavery patrols by the Royal and United States Navies made less effective by the rules-based order. Royal Navy crews discovered slavers had hoisted American flags to prevent their vessels from being searched, while the Americans could similarly not inspect Spanish-flagged vessels. ${ }^{13}$ Despite these legalities, using warships meant slave trade sanctions had at least some teeth. In parallel, Qing dynasty weakness created naval-led opportunities to coerce Imperial China's commercial exploitation. Britain, France and the United States used their sea and riverine power, especially steam gunboats, to force open trade with China for the three generations following the Second Opium War. ${ }^{14}$

The Crimean War produced Europe's first great power conflict in 40 years, albeit for limited goals. Naval rivals England and France used fleets to fight Russia in unforeseen ways. The Russians stayed in port, while coalition and joint command was split in four, according to nation and service, creating an unwieldy war by committee. ${ }^{15}$ French Army influence turned both fleets into tactical support for the Sevastopol siege, making

11 Benjamin Armstrong, Small Boats and Daring Men: Maritime Raiding, Irregular Warfare, and the Early American Navy (Norman, OK: Oklahoma, 2020), 143-146. For a contrarian view of counter-piracy, see Guy Chet, The Ocean is a Wilderness: Atlantic Piracy and the Limits of State Authority, 1688-1856 (Amherst: Massachusetts, 2014).

12 Jonathan Caverley and Sara McLaughlin Mitchell, "A Liberal case for Seapower?” War on the Rocks (25 February 2021), at https://warontherocks.com/2021/02/a-libe ral-case-for-seapower.

13 W.E.B. Dubois, The Suppression of the African Slave Trade to the United States of America 1638-1870 (New York: Longmans Green: 1896), 129, at https:/www.gute nberg.org/files/17700/17700-h/17700-h.htm\#Chapter_VIII, "Anti-slavery Operations of the US Navy," https://www.history.navy.mil/research/library/exhibits/anti -slavery-operations-of-the-us-navy.html and Andrew Gordon, The Rules of the Game (Annapolis: Naval Institute, 1996), 162-163. Kennedy, 165, notes the RN squadron counted 32 warships off Africa in 1847; the USN used two to four.

14 Matzke, 142-146, Kennedy, 166-167. See also Bernard D. Cole, Gunboats and Marines: The United States Navy in China, 1925-1928 (Wilmington: Delaware, 1982).

15 Andrew Lambert, "Arms Races and Cooperation: The Anglo-French Crimean War Coalition, 1854-1856," in Niels Bo Poulsen et al. (eds.), Coalition Warfare: An 
them ineffective during the failed attack on the city on 17 October 1854. Naval misuse prevailed into 1855, when General François de Canrobert recalled a sea raid on Kerch. His successor, General Aimable Pélissier, later launched that attack, opening the Sea of Azov to allied warships which ruined Russian logistics, ultimately starving Sevastopol. ${ }^{16}$ At least the coalition navies moved troops to Crimea and delivered supplies ashore to them.

Surprisingly, the Crimean War coalition hardly used its preeminence at sea to attack Russia's Baltic positions. Political concerns about Swedish intervention constrained fleet use, leading one contemporary British magazine to satirise naval efforts as:

What is the difference between the fleet in the Baltic and the fleet in the Black Sea? The fleet in the Baltic was expected to do everything and it did nothing; the fleet in the Black Sea was expected to do nothing and did it. ${ }^{17}$

Just as in the Black Sea, joint and combined command disputes slowed decisions. Still, Anglo-French power dominated the Baltic, raided Russian ports and landed siege artillery and troops to take the Åland Islands. ${ }^{18}$ Action stopped with the coalition's bombardment and wrecking of the Sveaborg (Finland's Suomenlinna) fort in August 1855; the war ended in March 1856. Despite squabbles, and while not decisive, the threat posed by allied navies had tied in place over 30\% of the Russian Army deployed to defend the Baltic coast, especially at Kronstadt. ${ }^{19}$

The First World War saw British, French and Italian fleets divide responsibility for Europe's periphery. Despite steamships and early radio, environmental limits on command and control cut the opportunities for cooperation at this scale. ${ }^{20}$ An exception was the Pacific, as mixed warship groups, including from Japan and Australia, hunted for the German East

Anthology of Scholarly Presentations at the Conference on Coalition Warfare at the Royal Danish Defence College, 2011 (Newcastle: Cambridge Scholars, 2013), 102105.

16 Lambert, 108-109.

17 Punch quoted in Kennedy, 174. See also Terrence Poulos, "The Baltic Gambit: The Royal Navy, Strategy, and Seapower in the Crimean War," unpublished paper (Univ. of Chicago, June 1987), 2, copy in author's possession.

18 Poulos, 21, 25-31.

19 Lambert, 111 and Poulos, 61-65.

20 Points acutely made in James Goldrick, Before Jutland: The Naval War in Northern European Waters, August 1914-February 1915 (Annapolis: Naval Institute, 2015), 3, and Gordon, Rules, 354-356. 
Asian Cruiser squadron. ${ }^{21}$ Tactically, from 1914 English submarines aided Russia in the Baltic and Black Seas, creating consternation but having little lasting effect. Imperial Germany did likewise, sending U-boats to reinforce the Ottomans in the Black Sea and Austria-Hungary in the Adriatic. ${ }^{22}$ Most notably, a 1915 Anglo-French joint force tried to open the Dardanelles. While conceptually promising, a lack of preparation and the committing of limited resources to pry open the Turkish straits disregarded the complex end the Entente sought. ${ }^{23}$ Its costly failure soured many nations' view of the potential of amphibious action for a generation.

The World War's latter half saw more tangible joint and combined successes. In October 1917, a German amphibious descent on Russia's Baltic islands, Operation Albion, leveraged much of the High Seas Fleet to pressure the Petrograd government. ${ }^{24}$ Elsewhere, German submarine attacks on merchant shipping forced the use of convoys, creating a shortage of escort warships. The Imperial Japanese Navy stepped into the gap in April 1917, committing 14 destroyers to shepherd Mediterranean convoys, scheduled by Britain. ${ }^{25}$ The newly co-belligerent United States sent destroyers to Ireland the next month, also under British command and receiving Royal Navy antisubmarine warfare training. American battleships joined the Grand Fleet as the Sixth Battleship Squadron, too, in November 1917. Commanders of both American units fashioned good personal relationships with their British counterparts, which constituted the human

21 David Stevens, In All Respects Ready: Australia's Navy in World War One (Melbourne: Oxford, 2014), 49, and Paul G. Halpern, A Naval History of World War I (Annapolis: Naval Institute, 1994), 89-90.

22 Halpern, 187-190, 199-205, 233 and Goldrick, Before, 224-228.

23 Nicholas Lambert, The War Lords and the Gallipoli Disaster: How Globalized Trade Led Britain to Its Worst Defeat of the First World War (Oxford: Oxford, 2021), 197198, Nicholas Lambert, Planning Armageddon: British Economic Warfare and the First World War (Cambridge: Harvard, 2012), 315-322, and Andrew Lambert, "The German North Sea Islands, the Kiel Canal and the Danish Narrows," in Michael Epkenhans and Gerhard Gro $\beta$ (eds.), The Danish Straits and German Naval Power 1905-1918 (Potsdam: Militärgeschichtliches Forschungsamt, 2010), 58-59.

24 Michael B. Barrett, Operation Albion: The German Conquest of the Baltic Islands (Bloomington: Indiana, 2008) and James Goldrick, After Jutland: The Naval War in Northern European Waters, June 1916-November 1918 (Annapolis: Naval Institute, 2018), 188-203.

25 Halpern, 393. 
side of the coalition. ${ }^{26}$ Combined naval operations had thus begun to assume a more modern nature.

After 1918 the wartime maritime coalition faded, with countries instead vying for position. Partly cooperating during the Russian Civil War, and the Balkan settling of accounts, navies resumed work in national terms. Exceptions included evacuating hundreds of thousands of civilians, delivering food aid, dealing with maritime safety and some support for the new Baltic states. ${ }^{27}$ Likewise, at the end of the 1930s, British and French fleets tried to enforce maritime non-intervention during the Spanish Civil War. Fascist Italian and National Socialist German ships completely evaded the embargo to support Francisco Franco, even using submarines to attack merchant ships, as the Soviet Union supported the Republicans. ${ }^{28}$ While a contemporary author labelled the British as "Naval Pimpernels" for rescuing civilian innocents from shore cities, a mission also conducted by the US Navy's Squadron 40-T showed that state interests predominated. ${ }^{29}$

The Second World War opened with France and Britain predominant at sea. Despite that strength, which allowed them to sink many Kriegsmarine ships, they could not prevent the German sea and air invasion of neutral Norway in April 1940.30 The subsequent fall of France, and Italy joining the Axis, reset the maritime balance. Italo-German Atlantic cooperation stayed limited to parallel submarine operations against Allied shipping, with several dozen Italian boats joining the Battle of the Atlantic, but not

26 Halpern, 359 and William N. Still, Crisis at Sea: The United States Navy in European Waters in World War I (Gainesville: Florida, 2004), 332-336 and 144 and Goldrick, After Jutland, 161-163 and 226-229. Commander Joseph Taussig, the USN destroyers' commander, personally knew Admiral John Jellicoe, First Sea Lord, both having been wounded on the same day fighting in the 1900 Boxer Rebellion, in China.

27 William N. Still, Victory Without Peace: The United States Navy in European Waters 1919-1924 (Annapolis: Naval Institute, 2018), 104-106, 146, 162-164, 176-177, 197-201, 227-229 and Stephen W. Roskill, Naval Policy Between the Wars. Vol. I: The Period of Anglo-American Antagonism, 1919-1929 (London: Collins, 1968), 141-143, 196.

28 Stephen W. Roskill, Naval Policy Between the Wars. Vol. II: The Period of Reluctant Rearmament (London: Collins, 1976), 372-376, 385, 388-390.

29 Kenneth Edwards, The Grey Diplomatists (London: Rich and Cowan, 1938), 242 and Willard Frank, "International Efforts to Contain the Spanish Civil War, 1936-1939" Canadian Commission on Military History (ed.), Maintien de la Paix de 1815 à Aujourd'hui/Peacekeeping 1815 to Today (Québec: CCMH, 1995), 184197.

30 Keith Bird, Erich Raeder: Admiral of the Third Reich (Annapolis: Naval Institute, 2006), 145-148. 
joining in group operations, the famous "Wolf Packs". In the Mediterranean, 68 U-boats reinforced the Regia Marina, achieving some success but at the ultimate cost of all the craft committed. ${ }^{31}$ Both nations operated a few submarines out of Penang, in current-day Malaysia, raiding Allied Indian Ocean shipping to support Imperial Japan. ${ }^{32}$

Axis subsurface threats drove the development of an Allied combined solution. Strategic coordination started in late 1941, as President Franklin Roosevelt ordered the US Navy to escort convoys halfway across the Atlantic, despite America still being neutral, then hand them over for protection by the Royal and Royal Canadian Navies. ${ }^{33}$ The step meant that even before the Pearl Harbor attack a combined convoy system, and tactics to manoeuvre and defend dozens of merchant ships, including use of air power, started developing for the Battle of the Atlantic. Shared methods soon extended to the Mediterranean, Caribbean and Arctic theatres.

Crucially, the Atlantic campaign laid the multinational groundwork and familiarity which created the trust needed among the Allies for them to conduct complex amphibious landings in Europe, especially in France. Without the Allies coordinating their resources, the price of failure could have been heavy: before the Normandy invasion, during combined Exercise Tiger in late April 1944, at Slapton Sands, German torpedo boats sank two American landing ships, killing 700 soldiers. ${ }^{34}$ For Pacific amphibious warfare advocates, the US Marine Corps needed to work out joint operations with the US Navy, especially on ship-to-shore movement and com-

31 For the BETASOM (Bordeaux Sommergibile) flotilla's success in early 1942, see Clay Blair, Hitler's U-boat War: The Hunters, 1939-1942 (New York: Random House, 1996), 508. On Mediterranean losses, see Blair, Hitler's U-boat War: The Hunted, 1942-1945 (New York: Random House, 1997), Appendix 7, 788-790. See also Bird, 169.

32 Jan Asmussen, "Amidst Abyss and Paradise-Germany's War in East Asia," in Jarosław Suchoples et al. (eds.), World War II Re-explored. Some Millennium Studies in the History of the Global Conflict (Berlin: Peter Lang, 2019), 285-318.

33 W.A.B. Douglas et al., No Higher Purpose: The Official Operational History of the Royal Canadian Navy in the Second World War, 1939-1943. Vol. II, Part 1 (St. Catharines: Vanwell, 2002), 172-174, 211-212.

34 ibid., 278-279 and W.A.B. Douglas et al., A Blue Water Navy: The Official Operational History of the Royal Canadian Navy in the Second World War, 1943-1945. Vol. II, Part 2. (St. Catharines: Vanwell, 2007), 185-186, 227 and Christopher D. Yung, Gators of Neptune: Naval Amphibious Planning for the Normandy Invasion (Annapolis: Naval Institute, 2006), 91-93, 158-160. 
mand relationships. The November 1943 bloodletting at Tarawa showed the wide seam between the two services, which was resolved thereafter. ${ }^{35}$

Defensive joint naval support deserves note. Starting in Norway, most notably at Dunkirk, and through the Greek, Crete and Dodecanese campaigns, Allied naval power repeatedly rescued endangered ground forces. Notably, the Axis did the same: in early 1943 the Imperial Japanese Navy pulled out much of the Guadalcanal garrison, as did the Germans and Italians from Sicily later that year. ${ }^{36}$ German and Rumanian troops enjoyed similar maritime rescues in late 1943 from the Caucasus and, less successfully, in 1944 from Crimea, while Nazi Germany's 1945 Baltic withdrawals represented the largest evacuation any service was able to do. In most of these withdrawals, success came despite facing stronger air or naval power.

In the Pacific, Allied combined operations experienced a rough passage. ABDACOM, American-British-Dutch-Australian Command, headed by a British field marshal, in February 1942 tried to halt Japan's drive on Indonesia. Harshly confirming command and control's centrality, the combined flotilla disastrously mixed three different sets of tactics, in two languages. ${ }^{37}$ Led by Royal Netherlands Navy Admiral Karel Doorman, and holding both a defensive advantage and near equal numbers, the Allies were largely destroyed by Japanese ships at negligible cost during the Battles of the Java Sea and Sunda Strait. Six months later a mixed USAustralian force, commanded by a Royal Navy rear admiral, received a similar drubbing at Savo Island. ${ }^{38}$ The painful lessons of these actions, shared amongst the Allies, built impetus for their ultimate success in 1945. They also put in place the foundations for shared and long-term joint amphibious practices honed in the central and south-western Pacific.

35 George C. Dyer, The Amphibians Came to Conquer: The Story of Admiral Richmond Kelly Turner (Washington: Naval History Division, 1969), 686-700.

36 Derived from Sarandis Papadopoulos, "An inferior naval power ashore: German Navy Baltic, Mediterranean and Black Sea Operations," in David Stevens and John Reeve (eds.), Sea Power Ashore and in the Air (Sydney: Halstead, 2007), 92105.

37 Samuel E. Morison, History of United States Naval Operations in World War II. Vol. 3: The Rising Sun in the Pacific, 1931-April 1942 (New York: Little Brown, 1948), 342-343, and War History Office of the National Defense College of Japan (Willem Remmelink, ed. and trans.), The Operations of the Navy in the Dutch East Indies and the Bay of Bengal (Leiden: Leiden, 2018), 412-414, 435-457.

38 Trent Hone, Learning War: The Evolution of Fighting Doctrine in the U.S. Navy, 1898-1945 (Annapolis: Naval Institute, 2018), 174-179. 
The early Cold War saw something new: peacetime interest in combined naval efforts, first among English-speaking allies, then for NATO, Australia, New Zealand and Japan. Preparing for antisubmarine warfare, now to resist the Soviet Navy, created the push for the approach. ${ }^{39}$ Despite politically untenable attempts to split defence production by adopting homogeneous equipment, shared command and control measures bridged the fleets instead. By 1952, the manual ATP 1: Allied Naval Maneuvering Instructions began teaching English-speakers the necessary tactics, which were soon translated with supporting communication rules and standardisation agreements. Reinforced by officer school exchanges and large exercises ("Mainbrace" off Norway in 1952 involved 200 ships, 1,000 airplanes and 80,000 people), the "interoperable" maritime alliance was put in place. Korean War combat, including three nations' warships at the Inchon amphibious landings in September 1950, was its first combat test. ${ }^{40}$ Use of NATO's maritime doctrine started spreading across the globe.

Still, there was much room for friction. In November 1956, a British and French fleet amphibiously attacked Gamel Abdul Nasser's Egypt during the Suez Crisis. The event saw use of naval weapons constricted by rules of engagement, the US Sixth Fleet unsupportive and a shared former colony of Canada fostering a United Nations' ceasefire and allied withdrawal. ${ }^{41}$ Likewise, command of nuclear weapons, treated nationally by the British, French and United States, became divisive, although compromises arose. As a NATO demonstration, the destroyer USS Claude V. Ricketts, captained and half-crewed by Americans, sidestepped the command issues and filled out its complement with West German, Hellenic,

39 Corbin Williamson, The U.S. Navy and Its Cold War Alliances, 1945-1953 (Lawrence: Kansas, 2020), Ch. 5, and Peter T. Haydon, “A Tale of Two Navies: Building the Canada-U.S. Cold War Naval Relationship" in Canadian Military History vol. 23: 3 \& 4 (Summer/Autumn 2014), 176-194.

40 ibid., 186-197 and Ch. 7, Anselm van der Peet, Out of Area: de Koninklijke Marine en multinational vlootoperaties 1945-2001 (Franeker: Van Wijnen, 2016), 534, Sean Maloney, Securing Command of the Sea: NATO Naval Planning, 1948-1954 (Annapolis: Naval Institute, 1995), 153-156 and Curtis Utz, Assault from the Sea: The Amphibious Landing at Inchon (Washington: Naval Historical Center, 1994), 14, at https://www.history.navy.mil/content/history/nhhc/research/publications/publica tions-by-subject/inchon.html.

41 Eric Grove, Vanguard to Trident: British Naval Policy Since World War Two (Annapolis: Naval Institute, 1987), 183-195 and Stephen Prince, "The Post-Imperial Relationship with the Royal Navy: On the Beach?" Canadian Military History vol. 23: $3 \& 4$ (Summer/Autumn 2014), 308. 
Italian, Royal Netherlands, Royal and Turkish Navy officers and sailors. ${ }^{42}$ A complete success in naval terms, the experiment did not resolve nuclear command divisions. Tactical and operational solutions, valuable in themselves, are no substitute for strategic cohesion. ${ }^{43}$

Given national command differences, NATO began deploying a group of a half-dozen escorts, with an oiler, named Standing Naval Force Atlantic -STANAVFORLANT from 1968. It is hard to overstate the impact of Standing Naval Forces upon the tactics and, vitally, the minds of allied sea service members. ${ }^{44}$ Reporting to the Supreme Allied Commander, Atlantic in Norfolk, a US admiral, each captain in the squadron led the force in rotation. Embodying the American-created and NATO-accepted "flexible response" doctrine, STANAVFORLANT was, and under a new name still is, a familiarisation and training unit in peacetime, a crisis response force and a capable armed multinational convoy escort in case of war. ${ }^{45} \mathrm{~A}$ Mediterranean version started in 1969, was formalised in 1992 and, with two mine warfare units, continues to work in parallel. Above all, through it "procedural interoperability has engendered a cultural interoperability of unstated but no less strong mutual understanding that guides how one does business during coalition warfare". 46 Backed by wider exchanges of people and shared schools, NATO ship crews have served together, know-

42 Andrew Priest, "In Common Cause': The NATO Multilateral Force and the Mixed-Manning Demonstration on the USS Claude V. Ricketts, 1964-1965" Journal of Military History 69: 3 (July 2005), 759-789 and Marco V. Kölln, "Marine und Multinationalität: Das Experiment Claude V.(Vernon) Ricketts" in Die Marine im Kalten Krieg 1956-1968 (Rostock: 37. Historisch-Taktische Tagung der Flotte, 1997), 125-143.

43 On a late 1960s' exercise which temporarily bridged NATO allies Greece and Turkey, see Sarandis Papadopoulos, "Partnership-Horacio Rivero, Jr. (19102000)," in John B. Hattendorf and Bruce A. Elleman (eds.) Nineteen-Gun Salute: Case Studies of Operational, Strategic, and Diplomatic Naval Leadership During the 20th and Early 21st Centuries (Newport: Naval War College, 2010), 152-153.

44 John B. Hattendorf, "NATO's Policeman on the Beat: The First Twenty Years of the Standing Naval Force, Atlantic, 1968-1988," in John B. Hattendorf, Naval History and Maritime Strategy (Malabar: Krieger, 2000) and Nicholas Tracy, A TwoEdged Sword: The Navy as an Instrument of Canadian Foreign Policy (Montreal and Kingston: McGill-Queens, 2012), 154-155.

45 Grove, 296.

46 Eric Lerhe, At What Cost Sovereignty? Canada-US Military Interoperabilty in the War on Terror (Halifax: Dalhousie, 2013), 5. In 2005 renamed Standing NATO Maritime Groups (SNMG) 1 (former STANAVFORLANT) and 2 (STANAVFORMED), and Standing NATO Mine Countermeasures Groups (SNMCMG) 1 and 2 . 
ing and trusting one another through these formations for nearly two generations.

The mid-Cold War extended multinational sharing to the Pacific. Held since 1971, starting with the Royal Australian, Canadian, United States and Royal Navies, the Rim of the Pacific (RIMPAC) exercise reinforced expertise and built familiarity. ${ }^{47}$ Conducted biennially near Hawai'i, it addressed the Soviet threat, with NATO procedures imported for Pacific use. Japan's Maritime Self-Defense Force (JMSDF) joined in 1980, affording those crews the chance to work with navies beyond their ally, the United States. Over time, participating ship and aircraft crews made the same efforts as their Atlantic counterparts. ${ }^{48}$ Other nations have joined in, briefly including the People's Liberation Army Navy in the $21^{\text {st }}$ century. As a measure of its value, one Australian officer described his service as making a "regular pilgrimage" to RIMPAC, a sentiment also reflected in the JMSDF's promotion of former exercise participants to the rank of admiral. ${ }^{49}$

Cold War actions in the Atlantic theatre confirmed and reinforced the utility of multinational operations. Perhaps the most robust exercise, Northern Wedding held every four years off Scandinavia, demonstrated different nations' fighting skill, while simultaneously testing concepts for evading Soviet naval and air power. ${ }^{50}$ Letting the allies share knowledge of their capabilities for great power competition with one another built confidence in NATO's deterrent strength. Behind the scenes, cooperation also grew as British and American submariners carefully shared their under-

47 In 1959 the UNITAS Exercise also started with South and North American naval participation. To the best of the author's knowledge, there have been no combined operations that have exploited these relationships.

48 Richard Hunt and Robert Girrier, "RIMPAC Builds Partnerships that Last" Proceedings vol. 137: 10 (October 2011), 76-77, Alessio Patalano, Post-war Japan as a Sea Power: Imperial Legacy, Wartime Experience and the Making of a Navy (London: Bloomsbury, 2015), 109, and Yōji Kōda, "From Alliance to Coalition, then Where? Japan and the US Navy Cooperative Strategy for the Twenty-First Century," in Alessio Patalano (ed.), Maritime Strategy and National Security in Japan and Britain (Leiden: Global Oriental, 2012), 211 and Narushige Michishita et al., Lessons of the Cold War in the Pacific: U.S. Maritime Strategy, Crisis Prevention, and Japan's Role (Washington: Wilson Center, 2015).

49 Jack McCaffrie, "The RAN and Australia's maritime security: options for the future," in David Stevens (ed.), Maritime Power in the 20 $0^{\text {th }}$ Century: The Australian Experience (St. Leonards: Allen \& Unwin, 1998), 267 and Patalano, Post-war, 129.

50 John F. Lehman, Oceans Ventured: Winning the Cold War at Sea (New York: W.W. Norton 2018), Ch. 6, and Eric Grove, Battle for the Fiords: NATO's Forward Maritime Strategy in Action (Annapolis: Naval Institute, 1991). 
standing of Soviet subsurface forces and tactics. In particular, the willingness of these crews to get "up close and personal" displayed mutual professionalism and trust in one another. ${ }^{51}$ Truly global maritime pressure helped deter the Soviet Union at sea.

The end of the Cold War changed the maritime balance again, with navies free to police the ocean commons, rather than readying themselves for great power competition. With the leading alliance and subsequent broader coalitions holding preponderant naval power, multilateral efforts accelerated, usually under United Nations (UN) authority. The first such effort enforced arms and oil sanctions against Iraq following Saddam Hussein's 1990 invasion of Kuwait. National rules of engagement, and limits of proprietary intelligence information, complicated the stopping and searching of ships trying to run the embargo. ${ }^{52}$ Despite the wear and tear of organising that embargo, it was to last until 2003. During Desert Storm, sanctions' enforcement worked alongside the coalition's aircraft carrier, naval gunfire and minesweeping efforts against Iraq..$^{53}$

In Europe, but "out-of-area" for NATO, Maritime Interception (or Interdiction) Operations (MIO) strove to manage the former Yugoslavia's civil war by blocking arms and fuel shipments. Ultimately named Sharp Guard, roughly a dozen ships plus aircraft continuously and laboriously tracked and sometimes questioned over 70,000 Adriatic ships over a 43-month period. ${ }^{54}$ NATO's Link-11 system helped share allied operational data and the latest version of ATP-1 guided manoeuvring. ${ }^{55}$ Given there were capable Serbian submarines and short-range missiles on the coast, crews needed to remain alert to any escalation. The mission also took on nuance, for po-

51 Peter Hennessy and James Jinks, The Silent Deep: The Royal Navy Submarine Service Since 1945 (London: Penguin, 2016), Ch. 9.

52 See Oct. 1990 Iraqi merchant ship Al Wasitti in Jeffrey G. Barlow, "U.S. Navy's Role in Maritime Interception Operations in the Arabian Gulf Region, 19912001," in Weir and Doyle, 29-30. For their legal frame see W. Heintschel von Heinegg (ed.) Visit, Search, Diversion and Capture: The Effect of the United Nations Charter on the Law of Naval Warfare (Bochum: Brockmeyer, 1995), 47, and Comment No.7 in ibid. by Heinz Dieter Jopp, 115-116.

53 Edward Marolda and Robert Schneller, Shield and Sword: The United States Navy and the Persian Gulf War (Washington: Naval Historical Center, 1998) and Anselm van der Peet, Out of Area: de Koninklijke Marine en multinationale vlootoperaties 1945-2001 (Wijnen: Uitgeverij Van, 2016).

54 Stephen Prince and Kate Brett, "Royal Navy Operations off the Former Yugoslavia: Operation Sharp Guard, 1991-1996" and Sarandis Papadopoulos, "The U.S. Navy's Contribution to Operation Sharp Guard," in Weir and Doyle, 45-99.

55 Norman Friedman, Network-Centric Warfare: How Navies Learned to Fight Smarter Through Three World Wars (Annapolis: Naval Institute, 2009), 88-91. 
litical limits meant some ships served under West European control, and as American policymakers debated whether to maintain the Balkans arms embargo or to arm the nascent state of Bosnia-Herzegovina instead. ${ }^{56}$ Naval commanders learned to "loosely couple" their formations, informally brokering what each ship could and could not do. ${ }^{57}$ Over time, Sharp Guard became joint, as UN peacekeepers inside the former Yugoslavia requested support. In response, naval air units took part in Operation Deliberate Force, which in May 1995 began targeting Serbian indirect fire weapons, prior to the arrival of NATO peacekeepers, the Implementation Force. ${ }^{58}$

In September 1999, the Pacific also saw a large combined and joint mission under UN auspices. Responding to ethnic and religious threats to the people of East Timor, Australia led Operation Stabilise to land a reinforced brigade of peacekeepers there, and for the next five months coalition ships supported it. ${ }^{59}$ A total of 36 ships responded, including the American cruiser USS Mobile Bay and the supply ship USNS Kilauea. Sailing to join Stabilise after the bilateral Australian-American Crocodile '99 exercise, their crews knew and fitted seamlessly into the Australian command and control structure, which again employed Link 11 to manage information. ${ }^{60}$ Given East Timor's isolation and poor infrastructure ashore, which forced the use of fuel-hungry helicopters, the broad coalition provided essential oilers-including the Canadian HMCS Protecteur, a long way from home-to deliver vital supplies.

The attacks on 11 September 2001 prompted a robust UN and NATO response at sea, the latter for the first time invoking its mutual defence obligation. Under Operation Enduring Freedom, both sought to deny Al Qaeda use of the open ocean to move people, under the rubric of Leadership Interdiction Operations, as well as to support operations ashore in

56 Peter T. Haydon, "Naval Peacekeeping: Multinational Considerations" in Peter T. Haydon, Navies in the Post-Cold War Era (Halifax: Center for Foreign Policy Studies, 1998), 61-62.

57 Mark D. Mandeles, The Future of War: Organizations as Weapons (Dulles, VA: Potomac, 2005), 150-153.

58 Prince and Brett, 69-70.

59 David Stevens, "The Combined Naval Role in East Timor" and Sarandis Papadopoulos, "A Limited Commitment to Ending Civil Strife: The U.S. Navy in Operation Stabilise," in Weir and Doyle, 101-165.

60 ibid., 119 \& 156. On Link 11 see Stephanie Hszieh et al., Networking the Global Maritime Partnership (Canberra: Sea Power Centre, 2014), 17-18. 
Afghanistan. ${ }^{61}$ A subsidiary effort, the US-sponsored Proliferation Security Initiative, also sought to prevent smuggling of technology, from North Korea and Iran, of weapons of mass destruction or their component parts. ${ }^{62}$ Reliant upon cooperative policies from participants, and highly demanding upon ships' crews, these tactics finalised methods for tackling the terrorist threat in a multidimensional way.

Over time and as in previous missions, strategic divergences split allies, with Turkey refusing to join in the 2003 invasion of Iraq, forcing maritime redeployment of the US Army $4^{\text {th }}$ Infantry Division through the Arabian Gulf. Canada, for internal political reasons, chose not to participate either. ${ }^{63}$ Throughout the combined and joint preparations for Operation Iraqi Freedom, and during the initial attack itself, Canadian Navy ships remained in the Arabian Gulf, bore their existing responsibilities and led Task Force 151, which was made up largely of states not part of the invading force. Two months later, the Canadians resumed pre-Iraq invasion information-sharing, as US ships rejoined the task force under multinational command. ${ }^{64}$ While allies and coalition partners will neither join every mission, nor commit forces of the same size as larger services, they do garner respect by showing professional competence. ${ }^{65}$ Few better indications showing durable trust at sea have arisen.

Other opportunities for maritime cooperation arose during humanitarian crises. Following a massive earthquake in December 2004 and resulting tsunamis across the Indian Ocean, coastal states desperately needed supplies delivered by sea. In response, dozens of warships from the region and beyond provided water, food and medical supplies, which were brought by sea and often made the last leg of the trip by shipborne helicopter to by-

61 Jeffrey G. Barlow, “The U.S. Navy's Role in Coalition Maritime Interception in Operation Enduring Freedom, 2001-2002" and Robert H. Caldwell, "The Canadian Navy, Interoperability, and U.S. Navy-Led Operations in the Gulf Region from the First Gulf War to 2003," both in Weir and Doyle, 167 \& 219, van der Peet, 532-533, and John Patch, "Maritime Interception Operations: Worth the Effort," in Sam J. Tangredi (ed.) The U.S. Naval Institute on Naval Cooperation (Annapolis: Naval Institute, 2015), 152-156.

62 Simon Reich and Peter Dombrowski, The End of Grand Strategy: US Maritime Operations in the $21^{\text {st }}$ Century (Ithaca: Cornell, 2017), 110-112.

63 Tracy, 269-270.

64 Caldwell, 250-252 and Lerhe, 260, 267.

65 van der Peet, 536. 
pass washed-out roads and bridges. ${ }^{66}$ Shortly thereafter, the devastation caused by Hurricane Katrina likewise made the Gulf of Mexico coast of the United States the recipient of assisting ships from Canada, Mexico and the Netherlands, as well as 14 from the US Navy. ${ }^{67}$ Similar naval responses occurred following earthquakes hitting Haiti in 2010 and Japan in 2011.68

During the $21^{\text {st }}$ century maritime operations unfolded, or reemerged, to challenge navies. The Arab Spring starting in 2011 unevenly instigated political change, with Libya's civil war an early focus. Under UN Security Council authorisation, over 40 warships (initially from two NATO standing maritime groups) staged two missions, the first coalition-run, the second an Alliance event. These forces began by eliminating the Libyan air defence system, and air units created a no-fly zone, which they then reinforced through an arms embargo, while protecting civilians on shore. ${ }^{69}$ Revolutions from Tunisia to Iraq also widely opened the floodgates for refugees to flow to Europe, creating opportunities for criminal human trafficking and abuse. The volume of seagoing migrants defied political solution, driving European Union maritime forces to reuse now-familiar Maritime Interception techniques for Operation Sophia, in this case stepping in to preserve human lives at sea for over five years. ${ }^{70}$

Similarly, Indian Ocean criminality, rooted both in illegal fishing and instability ashore, transformed an Enduring Freedom operating unit, Task Force 151, into a seagoing counter-piracy mission now in its thirteenth

66 Larissa Forster, Influence Without Boots on the Ground: Seaborne Crisis Response. Naval War College Newport Papers 39 (Newport: Naval War College Press, 2013), at https://digital-commons.usnwc.edu/cgi/viewcontent.cgi?article=1038\&context= usnwc-newport-papers, and Bruce Elleman, Waves of Hope: The U.S. Navy's Response to the Tsunami in Northern Indonesia. Naval War College Newport Papers 28 (Newport: Naval War College Press, 2007), at https:/digital-commons.usnwc.edu/ cgi/viewcontent.cgi? article=1029\&context=usnwc-newport-papers.

67 Brian Walsh, Support to the Hurricane Katrina Response by the Joint Force Maritime Component Commander: Reconstruction and Issues (Alexandria: Center for Naval Analyses, 2006), 81-87 at https://www.cna.org/CNA_files/PDF/D0013414.A4.pdf.

68 See Forster, Appendix A.

69 Christopher S. Chivvis, "Strategic and Political Overview of the Intervention," Deborah C. Kidwell, “The U.S. Experience: Operational” and Christina Goulter, "The British Experience: Operation Ellamy" in Karl P. Mueller (ed.), Precision and Purpose: Airpower in the Libyan Civil War (Santa Monica: RAND, 2015), 21-29, 123 and 158-159 at https://www.rand.org/content/dam/rand/pubs/research_repor ts/RR600/RR676/RAND_RR676.pdf and "Daily NATO Operation Unified Protector summaries," at https://www.nato.int/cps/en/natolive/news_71994.htm.

70 EUNAVFORMED “Operation Sophia," at https://www.operationsophia.eu/aboutus/\#chain_of_command. 
year. ${ }^{71}$ Under the European Union name of "Atalanta" and authorised by the UN, warships serve as escorts to maintain the commercial seagoing traffic flow off East Africa, with command of the task force rotating through contributing nations and using techniques descended from ATP-1. Better allied navies added flexibility to the escorts' responses, as their national rules of engagement can prove robust. ${ }^{72}$ Practice begun during the Cold War and developed into durable knowledge in the Arabian Gulf and Adriatic are the skills needed for these missions.

Written by a historian, the preceding list of combined and joint naval missions may seem encyclopaedic, even formless, and of little utility to either analysts or naval leaders. Nonetheless, some generalisations apply. First, across time individual national policies shaped when and how each country's vessels and crews worked together. As sovereign territory, warships can only do what their political leaders allow: Vice Admiral Codrington at Navarino, nearly two centuries ago, shows us the professional penalty for disobeying what policymakers require. The rules-based maritime order matters, but an individual country's politicians must decide when and how their armed services will fight. It also bears noting that political goals will change, sometimes quickly. Sensitivity to such constraints among ship captains and the admirals who lead them is, therefore, proper.

Second, given the Earth's vast oceans, coordinated multinational operations before 1920 were difficult, with wind power making combined ageof-sail battles rare. The much broader combined and joint actions of the steam, radio, submarine and aircraft era became possible through enabling technology, although working through strategic-level constraints still needed extensive advance preparation. The testing ground for such approaches became the Second World War's Battle of the Atlantic, which was essential to an Allied victory and was broadened by amphibious warfare. Its Cold War successor, alliance antisubmarine warfare preparation,

71 Martin N. Murphy, Small Boats Weak States Dirty Money: Piracy and Maritime Terrorism in the Modern World (London: Hurst, 2008), and European Union Naval Force (Op Atalanta) Somalia, "Operation Atalanta," at https://eunavfor.eu/. The example of suppressing South East Asian piracy is a useful context. See Ahmad Almaududy Amri, "Piracy in Southeast Asia: An Overview of International and Regional Efforts" in Cornell International Law Journal Online (vol. 1) 2014, at http://c ornellilj.org/piracy-in-southeast-asia-an-overview/.

72 European Union Naval Force (Op Atalanta) Somalia, "Operation Atalanta," at https://eunavfor.eu/ and Terry McKnight \& Michael Hirsch, Pirate Alley: Commanding Task Force 151 Off Somalia (Annapolis: Naval Institute, 2012), 93-94. 
cemented practices in place. It also bears noting that creating ways for ships to "plug and play", or unplug when so ordered, is a perishable skill. Vice Admiral Andrew Lewis, USN, writing in early 2021, noted that NATO needs renewal; during the 1970s and the 1950s, his predecessors had said the same thing. Indeed, throughout the entire period examined here, "Interoperability has to be constantly re-brokered, and also marketed", confirming the timelessness of the admiral's words. ${ }^{73}$

Most durably, these same recent admirals, captains and sailors have found ways to make their missions together work, by appreciating what their international colleagues brought to the table. The chief advantage of trustworthy allies and coalition partners is the willingness they bring to the table to share burdens. The above are case studies which historians and current-day analysts can explore further and use to understand the skills which crews and planners need by looking at the specific constraints on behaviour shown in each case. Successful work at sea demands professional respect formed over time. At the risk of repetition, multinational cooperation starts by developing trust: even professional discussions about manoeuvring ships before conducting a manoeuvre at a RIMPAC exercise can, for example, develop and demonstrate shared respect. Largely invisible outside navies, these capabilities are essential to continuing the international rules-based order at sea.

\section{Works Cited}

Amri, Ahmad Almaududy, "Piracy in Southeast Asia: An Overview of International and Regional Efforts" in Cornell International Law Journal Online (vol. 1) 2014, at http://cornellilj.org/piracy-in-southeast-asia-an-overview/, accessed 16 March 2021.

Armstrong, Benjamin, Small Boats and Daring Men: Maritime Raiding, Irregular Warfare, and the Early American Navy (Norman, OK: Oklahoma, 2020).

Asmussen, Jan, "Amidst Abyss and Paradise-Germany's War in East Asia," in Suchoples, Jarosław et al. (eds.), World War II Re-explored. Some Millennium Studies in the History of the Global Conflict (Berlin: Peter Lang, 2019), 285-318.

Barrett, Michael B., Operation Albion: The German Conquest of the Baltic Islands (Bloomington: Indiana, 2008).

Bird, Keith, Erich Raeder: Admiral of the Third Reich (Annapolis: Naval Institute, 2006).

73 Caldwell, in Weir and Doyle, 265 and Andrew Lewis, "Strengthen the Transatlantic Alliance,” in Proceedings 145: 3 (March 2021), 14-16. 
Blair, Clay, Hitler's U-boat War: The Hunted, 1942-1945 (New York: Random House, 1997).

Blair, Clay, Hitler's U-boat War: The Hunters, 1939-1942 (New York: Random House, 1996).

Caverley, Jonathan and Mitchell, Sara McLaughlin, "A Liberal case for Seapower?” War on the Rocks (25 February 2021), at https://warontherocks.com/2021/02/a-lib eral-case-for-seapower, accessed 26 February 2021

Chet, Guy, The Ocean is a Wilderness: Atlantic Piracy and the Limits of State Authority, 1688-1856 (Amherst: Massachusetts, 2014).

Cole, Bernard D., Gunboats and Marines: The United States Navy in China, 19251928 (Wilmington: Delaware, 1982).

Corbett, Julian S., England in the Seven Years War: A Study in British Combined Strategy (London: Folio Society, 2001).

Davis, Lance E. and Engerman, Stanley, Naval Blockades in Peace and War: An Economic History Since 1750 (Cambridge: Cambridge, 2006).

W.A.B. Douglas et al., A Blue Water Navy: The Official Operational History of the Royal Canadian Navy in the Second World War, 1943-1945. Vol. II, Part 2. (St. Catharines: Vanwell, 2007).

Douglas, W.A.B. et al., No Higher Purpose: The Official Operational History of the Royal Canadian Navy in the Second World War, 1939-1943. Vol. II, Part 1 (St. Catharines: Vanwell, 2002).

Dubois, W.E.B., The Suppression of the African Slave Trade to the United States of America 1638-1870 (New York: Longmans Green: 1896), at https://www.gutenb erg.org/files/17700/17700-h/17700-h.htm\#Chapter_VIII, accessed 25 February 2021.

Dyer, George C., The Amphibians Came to Conquer: The Story of Admiral Richmond Kelly Turner (Washington: Naval History Division, 1969).

Edwards, Kenneth, The Grey Diplomatists (London: Rich and Cowan, 1938).

Elleman, Bruce, Waves of Hope: The U.S. Navy's Response to the Tsunami in Northern Indonesia. Naval War College Newport Papers 28 (Newport: Naval War College Press, 2007) at https://digital-commons.usnwc.edu/cgi/viewcontent.cgi?article=1 029\&context=usnwc-newport-papers, accessed 9 March 2021.

European Union Naval Force (Op Atalanta) Somalia, “Operation Atalanta," at https://eunavfor.eu/, accessed 18 March 2021.

European Naval Force Mediterranean, “Operation Sophia," at https:/www.operati onsophia.eu/about-us/\#chain_of_command, accessed 16 March 2021.

Ferreiro, Larrie D., Brothers at Arms: American Independence and the Men of France \& Spain Who Saved It (New York: A.A. Knopf, 2016).

Forster, Larissa, Influence Without Boots on the Ground: Seaborne Crisis Response. Naval War College Newport Papers 39 (Newport: Naval War College Press, 2013) at https://digital-commons.usnwc.edu/cgi/viewcontent.cgi?article=1038\&context =usnwc-newport-papers, accessed 9 March 2021. 
Frank, Willard, "International Efforts to Contain the Spanish Civil War, 19361939," Canadian Commission on Military History (ed.), Maintien de la Paix de 1815 à Aujourd'hui/Peacekeeping 1815 to Today (Québec: CCMH, 1995).

Friedman, Norman, Network-Centric Warfare: How Navies Learned to Fight Smarter Through Three World Wars (Annapolis: Naval Institute, 2009).

James Goldrick, After Jutland: The Naval War in Northern European Waters, June 1916-November 1918 (Annapolis: Naval Institute, 2018).

Goldrick, James, Before Jutland: The Naval War in Northern European Waters, August 1914-February 1915 (Annapolis: Naval Institute, 2015).

Gordon, Andrew, The Rules of the Game: Jutland and British Naval Command (Annapolis: Naval Institute, 1996).

Grove, Eric, Battle for the Fiords: NATO's Forward Maritime Strategy in Action (Annapolis: Naval Institute, 1991).

Grove, Eric, Vanguard to Trident: British Naval Policy Since World War Two (Annapolis: Naval Institute, 1987).

Guilmartin, John F., Gunpowder and Galleys: Changing Technology and Mediterranean Warfare at Sea in the Sixteenth Century (London: Cambridge, 1974).

Halpern, Paul G., A Naval History of World War I (Annapolis: Naval Institute, 1994).

Hattendorf, John B. "NATO's Policeman on the Beat: The First Twenty Years of the Standing Naval Force, Atlantic, 1968-1988" in Hattendorf, John B., Naval History and Maritime Strategy (Malabar: Krieger, 2000).

Haydon, Peter T., "A Tale of Two Navies: Building the Canada-U.S. Cold War Naval Relationship," Canadian Military History vol. 23: 3 \& 4 (Summer/Autumn 2014), 176-194.

Haydon, Peter T., "Naval Peacekeeping: Multinational Considerations" in Haydon, Peter T., Navies in the Post-Cold War Era (Halifax: Center for Foreign Policy Studies, 1998).

von Heinegg, W. Heintschel (ed.) Visit, Search, Diversion and Capture: The Effect of the United Nations Charter on the Law of Naval Warfare (Bochum: Brockmeyer, 1995).

Hennessy, Peter and Jinks, James, The Silent Deep: The Royal Navy Submarine Service Since 1945 (London: Penguin, 2016).

Hone, Trent, Learning War: The Evolution of Fighting Doctrine in the U.S. Navy, 1898-1945 (Annapolis: Naval Institute, 2018).

Hunt, Richard and Girrier, Robert, "RIMPAC Builds Partnerships that Last" Proceedings vol.137: 10 (October 2011) 76-77.

Hszieh, Stephanie, et al., Networking the Global Maritime Partnership (Canberra: Sea Power Centre, 2014).

Kennedy, Paul M., The Rise and Fall of British Naval Mastery (London: Ashfield, 1983).

Kölln, Marco V., "Marine und Multinationalität: Das Experiment Claude V.(Vernon) Ricketts" in Die Marine im Kalten Krieg 1956-1968 (Rostock: 37. Historisch-Taktische Tagung der Flotte, 1997). 
Lambert, Andrew, "Arms Races and Cooperation: The Anglo-French Crimean War Coalition, 1854-1856," in bo Poulsen, Niels, et al. (eds.), Coalition Warfare: An Anthology of Scholarly Presentations at the Conference on Coalition Warfare at the Royal Danish Defence College, 2011 (Newcastle: Cambridge Scholars, 2013).

Lambert, Andrew, "The German North Sea Islands, the Kiel Canal and the Danish Narrows," in Michael Epkenhans and Gerhard Groß (eds.), The Danish Straits and German Naval Power 1905-1918 (Potsdam: Militärgeschichtliches Forschungsamt, 2010).

Lambert, Nicholas, The War Lords and the Gallipoli Disaster: How Globalized Trade Led Britain to Its Worst Defeat of the First World War (Oxford: Oxford, 2021).

Lambert, Nicholas, Planning Armageddon: British Economic Warfare and the First World War (Cambridge: Harvard, 2012).

Lehman, John F., Oceans Ventured: Winning the Cold War at Sea (New York: W.W. Norton 2018).

Lerhe, Eric, At What Cost Sovereignty? Canada-US Military Interoperabilty in the War on Terror (Halifax: Dalhousie, 2013).

Lewis, Andrew, "Strengthen the Transatlantic Alliance," in Proceedings 145: 3 (March 2021) 14-16.

McCaffrie, Jack, "The RAN and Australia's maritime security: options for the future," in Stevens, David (ed.), Maritime Power in the $20^{\text {th }}$ Century: The Australian Experience (St. Leonards: Allen \& Unwin, 1998).

Mahan. Alfred T., The Influence of Sea Power Upon History, 1660-1783 (Boston: Little Brown, 1890).

Maloney, Sean, Securing Command of the Sea: NATO Naval Planning, 1948-1954 (Annapolis: Naval Institute, 1995).

Mandeles, Mark D. The Future of War: Organizations as Weapons (Dulles, VA: Potomac, 2005).

Marolda, Edward and Schneller, Robert, Shield and Sword: The United States Navy and the Persian Gulf War (Washington: Naval Historical Center, 1998).

Matzke, Rebecca Berens, Deterrence Through Strength: British Naval Power and Foreign Policy under Pax Britannica (Lincoln: Nebraska, 2011).

McKnight, Terry, and Hirsch, Michael, Pirate Alley: Commanding Task Force 151 Off Somalia (Annapolis: Naval Institute, 2012).

Morison, Samuel E., History of United States Naval Operations in World War II. Vol 3: The Rising Sun in the Pacific, 1931-April 1942 (New York: Little Brown, 1948).

Mueller, Karl P. (ed.), Precision and Purpose: Airpower in the Libyan Civil War (Santa Monica: RAND, 2015) at https:/www.rand.org/content/dam/rand/pubs/researc h_reports/RR600/RR676/RAND_RR676.pdf, accessed 16 March 2021.

Murphy, Martin N., Small Boats Weak States Dirty Money: Piracy and Maritime Terrorism in the Modern World (London: Hurst, 2008).

Narushige Michishita et al., Lessons of the Cold War in the Pacific: U.S. Maritime Strategy, Crisis Prevention, and Japan's Role (Washington: Wilson Center, 2015). 
North Atlantic Treaty Organization, "Daily NATO Operation Unified Protector summaries," at https:/www.nato.int/cps/en/natolive/news_71994.htm, accessed 15 March 2021.

Palmer, Michael A., Command at Sea: Naval Command and Control since the Sixteenth Century (Cambridge: Harvard, 2005).

Papadopoulos, Sarandis, "Partnership-Horacio Rivero, Jr. (1910-2000)" in Hattendorf, John B. and Elleman, Bruce A. (eds.) Nineteen-Gun Salute: Case Studies of Operational, Strategic, and Diplomatic Naval Leadership During the 20th and Early 21st Centuries (Newport: Naval War College, 2010).

Papadopoulos, Sarandis, "An inferior naval power ashore: German Navy Baltic, Mediterranean and Black Sea Operations," in Stevens, David and Reeve, John (eds.), Sea Power Ashore and in the Air (Sydney: Halstead, 2007).

Patalano, Alessio, Post-war Japan as a Sea Power: Imperial Legacy, Wartime Experience and the Making of a Navy (London: Bloomsbury, 2015).

Patch, John, "Maritime Interception Operations: Worth the Effort," in Tangredi, Sam J. (ed.) The U.S. Naval Institute on Naval Cooperation (Annapolis: Naval Institute, 2015).

van der Peet, Anselm, Out of Area: de Koninklijke Marine en multinational vlootoperaties 1945-2001 (Franeker: Van Wijnen, 2016).

Poulos, Terrence, “The Baltic Gambit: The Royal Navy, Strategy, and Seapower in the Crimean War,” unpublished paper, Univ. of Chicago, June 1987.

Priest, Andrew, “'In Common Cause': The NATO Multilateral Force and the Mixed-Manning Demonstration on the USS Claude V. Ricketts, 1964-1965” Journal of Military History 69: 3 (July 2005), 759-789.

Prince, Stephen, "The Post-Imperial Relationship with the Royal Navy: On the Beach?" Canadian Military History vol. 23: 3 \& 4 (Summer/Autumn 2014), 296310.

Reich, Simon and Dombrowski, Peter, The End of Grand Strategy: US Maritime Operations in the $21^{\text {st }}$ Century (Ithaca: Cornell, 2017).

Rodger, N.A.M., The Command of the Ocean: A Naval History of Britain, 1649-1815 (New York: W.W. Norton, 2005).

Roskill, Stephen W., Naval Policy Between the Wars. Vol. II: The Period of Reluctant Rearmament (London: Collins, 1976).

Roskill, Stephen W., Naval Policy Between the Wars. Vol. I: The Period of Anglo-American Antagonism, 1919-1929 (London: Collins, 1968).

Stevens, David, In All Respects Ready: Australia's Navy in World War One (Melbourne: Oxford, 2014).

Tracy, Nicholas, A Two-Edged Sword: The Navy as an Instrument of Canadian Foreign Policy (Montreal and Kingston: McGill-Queens, 2012).

Still, William N., Victory Without Peace: The United States Navy in European Waters 1919-1924 (Annapolis: Naval Institute, 2018).

Still, William N., Crisis at Sea: The United States Navy in European Waters in World War I (Gainesville: Florida, 2004). 
U.S. Naval History and Heritage Command, "Anti-slavery Operations of the US Navy," https://www.history.navy.mil/research/library/exhibits/anti-slavery-operat ions-of-the-us-navy.html, accessed 25 February 2021.

Utz, Curtis, Assault from the Sea: The Amphibious Landing at Inchon (Washington: Naval Historical Center, 1994), at https:/www.history.navy.mil/content/history/ nhhc/research/publications/publications-by-subject/inchon.html

Walsh, Brian, Support to the Hurricane Katrina Response by the Joint Force Maritime Component Commander: Reconstruction and Issues (Alexandria: Center for Naval Analyses, 2006), at https://www.cna.org/CNA_files/PDF/D0013414.A4.pdf, accessed 10 March 2021.

War History Office of the National Defense College of Japan (Willem Remmelink, ed. and trans.), The Operations of the Navy in the Dutch East Indies and the Bay of Bengal (Leiden: Leiden, 2018).

Weir, Gary and Doyle, Sandra (eds.), You Cannot Surge Trust: Combined Naval Operations of the Royal Australian Navy, Canadian Navy, Royal Navy, and the United States Navy 1991-2003 (Washington: Naval History and Heritage Command, 2013).

Williamson, Corbin, The U.S. Navy and Its Cold War Alliances, 1945-1953 (Lawrence: Kansas, 2020).

Willis, Sam, Fighting at Sea in the Eighteenth Century: The Art of Sailing Warfare (Woodbridge: Boydell, 2008).

Yōji Kōda, "From Alliance to Coalition, then Where? Japan and the US Navy Cooperative Strategy for the Twenty-First Century," in Patalano, Alessio (ed.), Maritime Strategy and National Security in Japan and Britain (Leiden: Global Oriental, 2012).

Yung, Christopher D., Gators of Neptune: Naval Amphibious Planning for the Normandy Invasion (Annapolis: Naval Institute, 2006). 
